\title{
Losses of Sucrose in Cut Cane Kept under Shade or Sun for Different Periods
}

\author{
E. Boneta-García and M. A. Lugo-López ${ }^{1}$
}

\section{INTRODUCTION}

The storing of cane in the mill yard prior to processing has long been a matter of concern because of probable sucrose losses to the farmer. In 1919 a Report was issued from Hawaii concerning the losses in cane-juice quality due to storage (6)..$^{2}$ In 1926 Cross (1) stated that the most important loss in the Java sugar industry arose from delays in milling. He recognized the differential behavior of different sugarcane varieties in this respect. Lauritzen and Balch (4), Rosenfeld (7), and again Lauritzen (2,3) were also concerned about deterioration of cane and losses occurring in stored cane before milling. In general, it is usually recognized that appreciable losses may occur when milling is delayed more than 1 or 2 days after harvesting. Such losses are greater if conditions favoring drying prevail.

This paper reports on a study conducted to determine the losses in sucrose content of several leading commercial sugarcane varieties stored for various intervals after harvest either in shade or under the sun. The results might throw additional light on this problem in general, and on varietal behavior in particular, and help farmers and processors as well to schedule their harvesting and milling operations on a more favorable basis. Storage conditions in the mill yard may be improved, if necessary, in order to avoid or at least reduce to a minimum sucrose losses in the interval between harvesting and milling.

\section{MATERIALS AND METHODS}

Among the sugarcane varieties studied were P.R. 980, P.O.J. 2878, and M. 336, all leading commercial canes that occupy far over 50 percent of the total area of this corp in Puerto Rico. Varieties H. 32-8560, P.R. 1000, and P.R. 902 were also included in the test. P.R. 980, a new variety, has replaced the commercial P.O.J. 2878 and M. 336. A set of samples of 200 stalks from each of the 6 varieties was obtained and divided in 2 groups of 100 stalks each. One group was kept in the shade and the other under the sun, as is usual in mill yards in Puerto Rico. Each group was further split into samples of 10 stalks each with a total of 120 samples for the whole set,

1 Agronomist in Charge of the Gurabo Substation and Assistant Director of the Agricultural Experiment Station, University of Puerto Rico, Río Piedras, P.R., first set respectively.

2 Italic numbers in parentheses refer to Literature Cited, p. 194. 
60 under shade and 60 under the sun. One sample of each variety from each group was ground during the first, second, third, fourth, fifth, sixth, eighth, tenth, twelfth, and fifteenth day following harvesting. A hydraulic squier mill was used. This mill has 3 rollers, $12 \times 16$ inches each with an average of 6.4 r.p.m. using a 10-hp. electric motor. The rollers exerted a pressure in the extraction of the juice of 29 tons per square inch (5).

A second set of samples was taken from the same field used previously some 20 days after the first set, but only four varieties were included, namely, P.O.J. 2878, M. 336, H. 32-8560, and P.R. 902. The procedure followed was identical as with the first batch of samples, except that grinding was done only during the first, sixth, eighth, tenth, twelfth, and fifteenth days after harvesttime.

\section{RESULTS AND DISCUSSION}

The effect of storage upon sucrose losses of each variety can be observed in figures 1 and 2 for each respective set of samples. Generally the daily percentage reduction in sucrose attributable to storage after harvesting was significant. The differential behavior of varieties can be clearly observed from these graphs. Variety M. 336 was the least affected by storage while P.R. 1000 was the most adversely affected variety. Both sets of samples behaved similarly in spite of the 20-day difference between harvesttimes. Figures 1 and 2 further show that there were no essential differences in sucrose losses whether the cane was stored under the sun or protected by shade. Although the general trend is for slightly higher losses in sun-exposed cane the differences did not attain significance, as was revealed by the statistical treatment of the data. The alternating decreases and increases, in some cases, of sucrose-percent-cane can probably be explained on a basis of loss or gain of moisture during storage, which, in turn, depends mainly on variable weather factors.

Coefficients of regression for the daily percentage reduction in sucrose are shown in table 1 . The general relation is given by the following:

$$
\begin{aligned}
& \text { Sucrose-percent-cane }=a+b, \text { where } \\
& a=\text { the average initial sucrose content, and } \\
& b=\text { the number of days in storage. }
\end{aligned}
$$

Average $b$ was obtained for each variety when no significant differences were observed between the regression coefficients for sun-stored and shadestored cane. In both sets of data the $b$ 's for varieties differed significantly, therefore, no average $b$ could be worked out for any variety in general.

The average daily losses of sucrose when the data from the two sets of samples were combined are shown in table 2. This analysis confirms the graphic picture obtained from figures 1 and 2 regarding differential behavior of varieties as to losses in sucrose-percent-cane when stored prior to milling. 

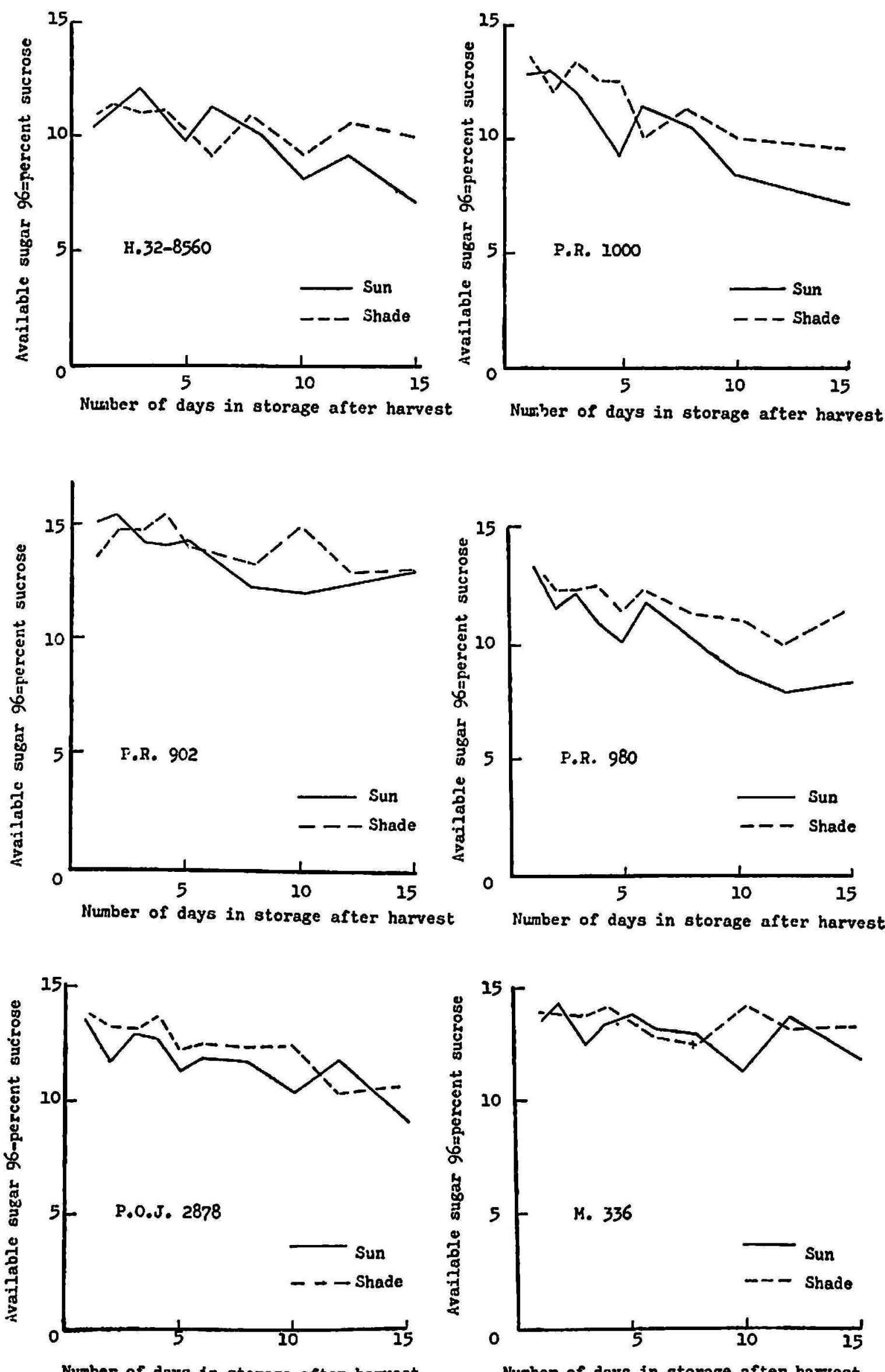

Frg. 1.-Effect of storage on sucrose losses by each of 6 sugarcane varieties in first set of samples. 


\section{SUMMARY}

Data are presented in this paper concerning the losses of sucrose by six sugarcane varieties stored either in the shade or under the sun, as is the common procedure in mill yards in Puerto Rico. The varieties included in

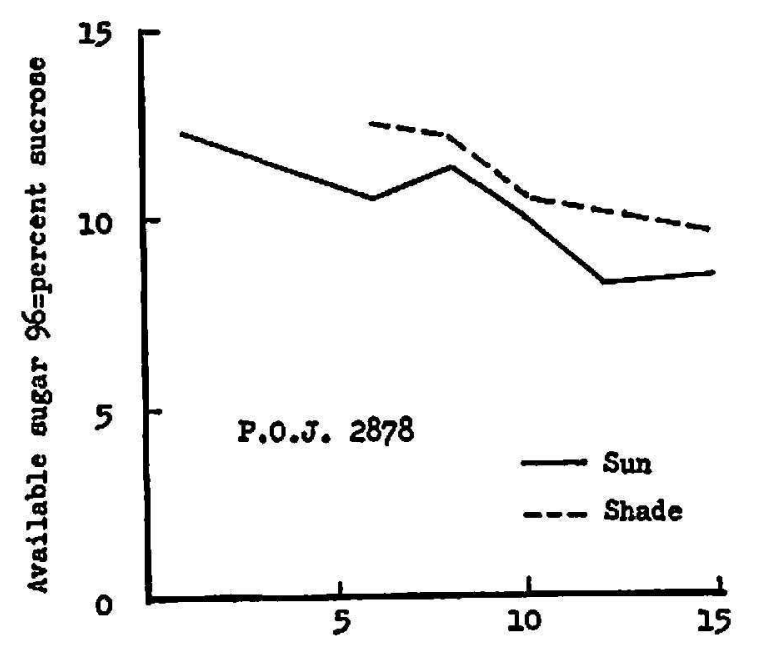

Number of days in storage after harrest

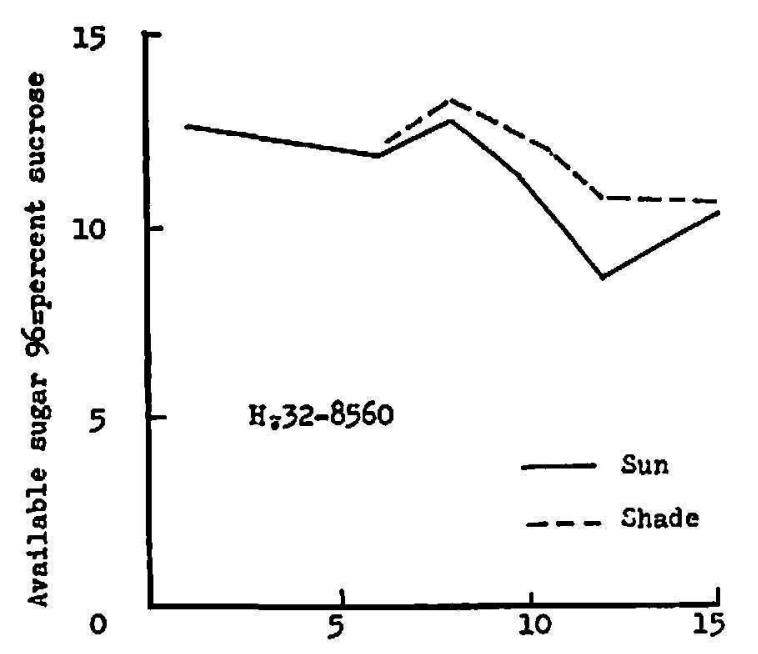

Number of days in storage after harvest

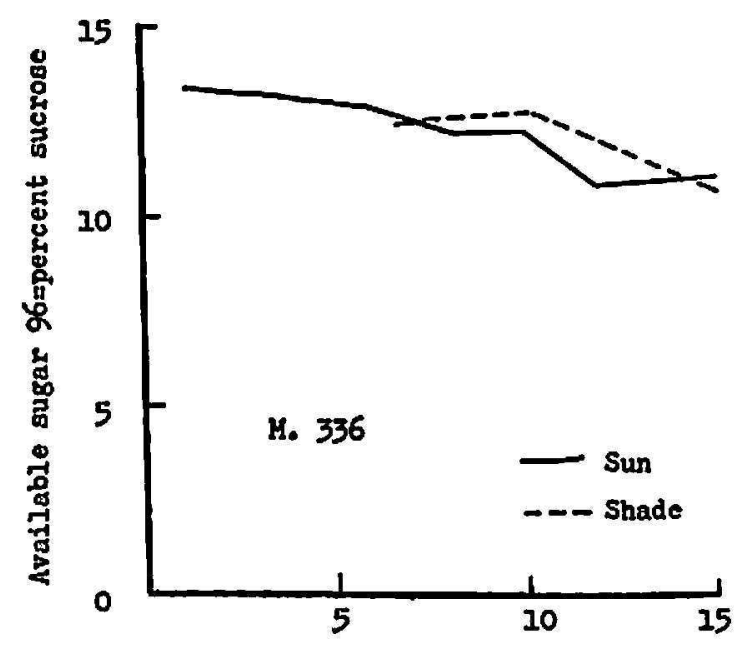

Nunber of dajs in storage after harvest

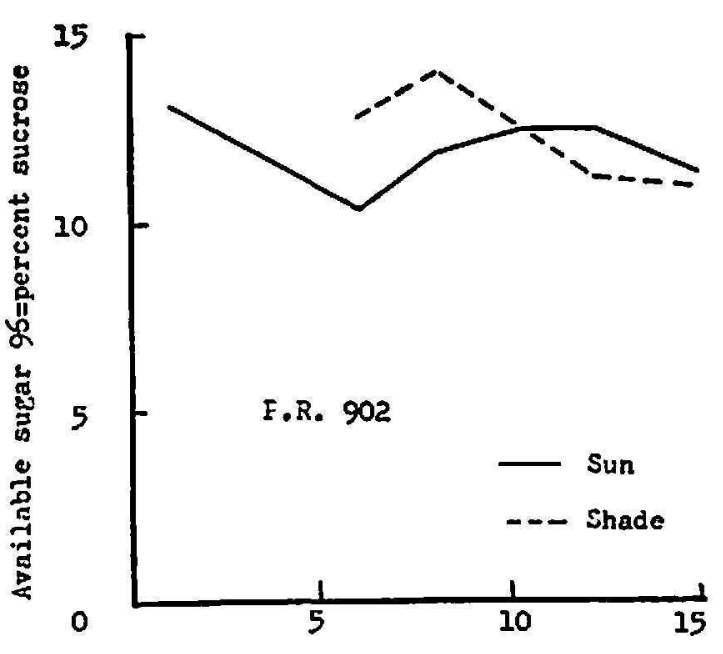

Number of days in storage after harvest

Fig. 2.-Effect of storage on sucrose losses by each of 4 sugarcane varieties in second set of samples.

the study were P.R. 980, P.O.J. 2878, M. 336, H. 32-8560, P.R. 1000, and P.R. 902. Two sets of samples, or a total of 120 samples of 10 stalks each, were stored for 20-day intervals following harvest. The daily percentage reduction in sucrose attributable to storage was significant. There were no essential differences whether storage was in shade or under the sun. The differential behavior of the six varieties was rather marked. Varicty M. 336 
TABLE 1.-Losses of sucrose by 2 lots of sugarcane of 6 varieties that were harvested and placed in storage either in the shade or under the sun ${ }^{1}$

\begin{tabular}{c|c|c|c|}
\hline Variety & $\begin{array}{c}\text { Daily percentage sucrose reduction } \\
\text { during- }\end{array}$ & $\begin{array}{c}\text { Average daily } \\
\text { reduction }\end{array}$ & $\begin{array}{c}\text { Average initial } \\
\text { sucrose content }\end{array}$ \\
\cline { 2 - 3 } & Sun storage & Shade storage & \\
\hline
\end{tabular}

First set of samples

\begin{tabular}{|c|c|c|c|c|}
\hline $\begin{array}{l}\text { P.O.J.2878 } \\
\text { M.336 } \\
\text { H.32-8560 } \\
\text { P.R.1000 } \\
\text { P.R.902 } \\
\text { P.R.980 }\end{array}$ & $\begin{array}{l}0.1593 \\
.1171 \\
.2608^{* *} \\
.4363^{* *} \\
.2340^{* *} \\
.3592^{* *}\end{array}$ & $\begin{array}{l}0.2299 \\
.05943 \\
.09326 \\
.3099 \\
.1100 \\
.1868^{*}\end{array}$ & $\begin{array}{l}0.1046 \\
.08726^{*} \\
.1770^{* *} \\
.3731^{* *} \\
.1720^{* *} \\
.2730^{* *}\end{array}$ & $\begin{array}{l}13.30 \\
13.93 \\
11.47 \\
13.47 \\
15.18 \\
12.92\end{array}$ \\
\hline \multicolumn{5}{|c|}{ Second set of samples } \\
\hline $\begin{array}{l}\text { P.O.J.2878 } \\
\text { M.336 } \\
\text { M.32-8560 } \\
\text { P.R.902 }\end{array}$ & $\begin{array}{c}0.2840^{* *} \\
.1900 \\
.2221 \\
.05338\end{array}$ & $\begin{array}{l}0.3287 \\
.2383^{*} \\
.2375 \\
.2930\end{array}$ & $\begin{array}{l}0.2948 \\
.2017^{* *} \\
.2258 \\
.1111\end{array}$ & $\begin{array}{l}13.04 \\
14.00 \\
13.49 \\
13.13\end{array}$ \\
\hline
\end{tabular}

$1 *$ Regression coefficient significant at the 5 -percent level; ** regression coefficient significant at the 1-percent level.

TABLE 2.-Average daily losses of sucrose by 2 sets of samples of sugarcane of 6 varieties stored either under the sun or in shade

\begin{tabular}{l|c|c}
\hline \multicolumn{1}{c|}{ Variety } & Average daily sucrose losses & Average initial sucrose content \\
\cline { 2 - 3 } P.0.J.2878 & $0.2296^{* *}$ & 13.21 \\
M.336 & $.1273^{* *}$ & 13.84 \\
H.32-8560 & $.1941^{*}$ & 12.18 \\
P.R.1000 & $.3731^{* *}$ & 13.47 \\
P.R.902 & $.1507^{* *}$ & 14.47 \\
P.R.980 & $.2730^{* *}$ & 12.92 \\
\hline Average & $0.2116^{* *}$ & 13.35 \\
\hline
\end{tabular}

$1 *$ Regression coefficient significant at the 5 -percent level; ${ }^{* *}$ regression coefficient significant at the 1-percent level.

2 The average daily losses for varieties P.R.1000 and P.R.980 represent the data obtained from 1 set of samples. This is also true for the average initial amount of sucrose for the same varieties.

was the least affected while P.R. 1000 was the most adversely affected variety.

\section{RESUMEN}

Se presentan aquí datos con relación a las pérdidas de sacarosa de seis variedades de caña dejadas bajo sombra o bajo sol, como sc acostumbra 
hacer en las plazas de las centrales azucareras de Puerto Rico. El estudio incluyó las variedades P.R. 980, P.O.J. 2878, M. 336, H. 32-8560, P.R. 1000 y P.R. 902. Dos grupos de muestras, con un total de 120 muestras de 10 cañas cada una, se cortaron a un intervalo de 20 días y se dejaron bajo las condiciones arriba descritas. Las muestras se molieron a varios intervalos después de la cosecha. La reducción diaria de sacarosa, la cual puede atribuirse al almacenaje antes de la molienda, fué significativa. Las distintas variedades de caña se comportaron diferentemente. La variedad M. 336 fue la que menos se afectó de todas, pero la P.R. 1000 sufrió pérdidas considerables de sacarosa durante el período de almacenaje.

\section{LITERATURE CITED}

1. Cross, W. E., The most important loss in making sugar from Java sugarcane, Int. Sugar J. 28 245-8, 1926.

2. Lauritzen, J. I., Losses of sucrose in mill cane during the interval between cutting and milling in Louisiana, Sugar J. 10(5) 3-7, 1947.

3. - Losses of sucrose in mill cane during the interval between cutting and milling in Louisiana, Sugar $J .10(6)$ 8-13, 1947.

4. Lauritzen, J. I., and Balch, R. T., Storage of Mill Cane, USDA Tech. Bul. 449, 1934.

5. Méndez-Roig, F., and Samuels, G., Sugarcane variety trials in Puerto Rico, 195155, J. Agr. Univ. P.R. 41(3) 147-60, 1957.

6. Report of the Exp. Sta. Committee of the Hawaiian Sugar Planters Assn., pp. 45-6, 1919.

7. Rosenfeld, A. H., Deterioration of harvested sugarcane in Egypt, Trop. Agr. 19 133-68, 1942. 